2001

\title{
Inquiry and Activism in Law and Society
}

Frank W. Munger

New York Law School, frank.munger@nyls.edu

Follow this and additional works at: https://digitalcommons.nyls.edu/fac_articles_chapters

Part of the Law and Society Commons

\section{Recommended Citation}

Law \& Society Review, Vol. 35, Issue 1 (2001), pp. 7-20

This Article is brought to you for free and open access by the Faculty Scholarship at DigitalCommons@NYLS. It has been accepted for inclusion in Articles \& Chapters by an authorized administrator of DigitalCommons@NYLS. 
Presidential Address

Inquiry and Activism in Law and Society

Frank Munger

\section{Hearing the Call of Activism}<smiles>C1CCC1</smiles>

wo events in the past twelve months have made me think about the law and society field and activism-two events and many years of telling myself that our field is about more than research.

The first event was Bette Sikes's response to the recognition she received from Austin Sarat, at last year's annual meeting, for her long years of service as production manager of the Law $\mathcal{E}^{2}$ Society Review. Bette, as always, cut to the heart of the matter with her parting advice, "Y'all should learn to write.".

As I learned to appreciate when I was editor of the Review, there is a larger lesson in Bette's advice-the importance of communicating so that we can be heard and have an effect. But the problem of communicating and affecting does not stop when we have our prose in order. Behind that concern is the still larger question about who we want our work to influence and how. The inception of the law and society field in North America, and in many other societies, was motivated by a belief in the simple proposition that law should stand for equality and for justice. Law and society researchers provided mounting evidence that law did not meet such high ideals. Our research appeared to have some significance in the fight for equality and justice. We

I have incurred many debts along the way to this presidential address, some going back to graduate school and the origins of my interest in the relationship between activism and social science research. I am particularly indebted to two friends who read many drafts, helped me bridge gaps in my thoughts, and struggled to make my prose coherent-Carroll Seron and David Engel. Many contributed valuable ideas and criticism as well as good advice about further readings, which I faithfully pursued even though I could not discuss them all in the short text that I had to prepare. They include Elizabeth Heger Boyle, Sara Cobb, Pablo DeGreiff, Bryant Garth, Christine Harrington, Susan Hirsch, Sally Merry, Kim Scheppele, Ann Shalleck, and Mariana Valverde. 
agreed with Lawrence Friedman's observation that "law is too important to be left to the lawyers."

A second event occurred in August 1999 that deeply moved me and created a sharper focus. Neelan Tiruchelvam, Sri Lankan human rights scholar and our longstanding law and society colleague, was assassinated for his peaceful activism in resolving the violent conflict in Sri Lanka between the Sinhalese majority and the Tamil minority. Neelan will be remembered by those who met him as one of the kindest and gentlest of persons. His legacy as an activist was large. He was an important figure in the Sri Lankan Parliament and a founder of two of Sri Lanka's bestknown social science research institutions, the International Centre for Ethnic Studies and the Law and Society Trust. As an internationally known human rights scholar and activist his voice carried great weight. Since his death I have been considering what I should learn from the life of this man that I admired.

At the top of the list might be Neelan's hopes for law. Neelan wrote about the promise of the judiciary in deeply divided plural societies, noting that most of the violent conflicts since World War II have involved divisions of racial and ethnic identity. His hopes also included solutions for the quiet violence of starvation and exclusion from opportunity for a quality life. He was drawn by the moral power of law to address these problems.

As our field goes global, I see a reawakening of the earlier interest in justice and equality, and in power, class, race, ethnicity, and religion. In North America, the end to the intellectual turbulence created by the cold war may have made it easier to perceive injustice. We see more clearly, perhaps, the disparity between extremes of poverty and power on one hand and optimistic claims for free markets and world governance on the other. A quarter of the world population lives on less than $\$ 1$ per day. Poverty is not just about money. Economist Amartya Sen has said, "[P] overty must be seen as the deprivation of basic capabilities rather than merely as low incomes" (1999:87). Capabilities, in turn, according to Sen, are "substantive freedoms the individual has reason to value" (ibid). Thus, world poverty cannot be understood without considering substantive freedoms, governanceand law.

As the vision of world problems becomes clearer, so also does our perception of race, gender, and poverty in all societies, including North America. Amartya Sen, once again, brought to the attention of the world that African-American men in urban America have a shorter life expectancy than men in Bangladesh or the poorest state in India.

This is an important moment to consider how globalization may help us understand and perhaps redefine activism at the heart of the law and society project. Global change is energizing the field. We are being led by world events, as well as events in 
our own societies, to an understanding that the stakes in law and society research are high. Yet, all of my conventional training in the social sciences and my experience in academic institutions raises questions about the role that activism can play in our field.

I am aware that an activist scholar may experience tension between activism and inquiry. Activism builds upon insight to create a durable commitment to a politics of change. But insight, if honestly pursued, can also lead the scholar in unexpected directions. Questions that are worth posing for our inquiry do not have easy or predictable answers. Nor does our insight, imagination, and thus the motivation for research, always lie in the politically prescribed direction. The next question and the question after that may lead down an unforeseen path. Thus, our commitment to action may seem to be at odds with our commitment to scholarship.

Although activism and inquiry may at times exist in tension with one another, I believe that activism can strengthen our research rather than undermine its validity, and that inquiry can benefit activism rather than frustrate it. The conflict itself may be a false perception. Boa Santos has recently asked why it has been so difficult to construct a critical theory that will guide us toward a more humane society. A critical theory, Santos suggests, is one that considers "reality" as a field of possibilities, a theory that guides research in its assessment of the "variation that exists beyond what is empirically given" (1998:122). In precisely this sense, our activism pushes inquiry to become an ally of progressive change.

The tension and creativity in the relationship between activism and inquiry may be better understood when viewed through the different ways in which scholars engage in their work and with the larger community. In the rest of my talk I will explore some of the meanings and practices of activism in the law and society field, and I will do this by looking in particular at the work of scholars in several different cultures and regions of the world.

\section{Activism as Engagement}

C. Wright Mills wrote that the social scientist is a teacher, helping other citizens to act "with historical consequence" (1959:192). By helping others understand the wider meaning of their historically situated lives, the scholar increases the likelihood and effectiveness of participation by ordinary citizens in a democratic society. As a graduate student in the civil rights era, this was enough for me.

During the optimistic ferment of the 1960s, identity, research, and activism came together for many of us. Younger scholars like me were drawn to the law and society field because it promised to reinforce something we had discovered in our 
own lives. We wanted engagement with problems of justice and the search for knowledge that would bring social practice closer to egalitarian and democratic ideals.

What was the connection between our activism and our scholarship at that earliest stage? Joyce Ladner (1971), author of a profound study of poor black women, Tomorrow's Tomorrow, explains how her civil rights activism awakened her vision as a scholar. Ladner grew up in Hattiesburg, Mississippi, during the civil rights movement. As a graduate student in the 1960s she realized that she could not accept "playing the role of dispassionate scientist." More importantly, she believed that the angle of vision afforded by her civil rights background was important. That angle of vision enabled her to hear and observe things that earlier scholars had often overlooked. Ladner rejected the "deviance/pathology" model of black family life and black women. She viewed black women, though poor, as "resourceful, normal women who were simply trying to cope with some of the harsher conditions of life" (1971:xii). She wrote, "What other scholars had traditionally viewed as weaknesses and pathology, I chose to view as strength and coping strategies in dealing with stress" (ibid). As a black woman activist, Ladner could understand the lives of black women in a unique way, and her insight provided a starting point for her research. At the same time, she discovered that her research ultimately explored her own identity as a black woman.

We discovered, like Ladner, that to be fully engaged in our research and to be activists required two commitments. First, our scholarship required respect for the subjects of our researchnot only for the meaning that their lives had for them but for the ends they valued. Without acquiring this understanding from our research subjects, we could hardly know what is important in the world, what equality or justice might mean, or which changes might matter and which would not. This face of activism-engagement with subjects-requires humility about our understanding of the needs and the goals of action.

Second, we learned more about our commitment to discover, as Mills (1959) suggests, the broader historical relevance of action, including its implications for change. This proved more difficult.

The growing complexity of our understanding of law has made simple models of egalitarian legal reform implausible. We have left behind hopes that exposing the shortcomings of liberal legal institutions will lead directly to change. Faithfulness to insight has led law and society scholars away from studies of liberal legal institutions on their own terms and toward highly contextualized studies of law in organizations, in communities, in families, in everyday lives. Powered by a critique of law that decenters or deconstructs the authority of law, law and society research locates 
the role of law in the very fabric of social relationships, consciousness, and identity.

Ladner's exploration of the origins of her insight, and her celebration of self-discovery, reminds us that there are creative and valuable connections between activism and inquiry. Highly contextualized studies may at first seem an impediment to activism. In fact, they are the point of convergence between inquiry and activism. Contextualization is the strength of Ladner's research. Ladner's insight is realized as she gets to know her interviewees and they reveal their lives to her. This moment of contact and mutual awareness is filled with possibilities for the future, as well as with the meaning of the present. Ladner's activism thrives on local knowledge, but local knowledge informed as well by her understanding of the historical moment in the development of civil rights.

Similarly, our research may lead us to view law, as Karl Llewellyn did, as the most local of institutions. For precisely that reason, our activism benefits not only from local knowledge of the terrain of law but also from interpretation that connects local context to social change within a larger political and social situation. The interpretive resources provided by law and society scholars from very different angles of vision may suggest unseen potentialities within our own communities and institutions.

As a field of study, creative interaction between activism and inquiry has been inspired through cross-fertilization among scholars from different backgrounds, not only scholars of different races and genders or from different disciplines but scholars from different cultures and different societies. I have admired the activism of some of our colleagues in non-North American societies, and through their work, we may gain a richer breadth of insight into the connections between activism and inquiry.

\section{Examples}

In his book on the judiciary in plural societies, Neelan Tiruchelvam (1987) expresses faith in the power of law to reinforce important political values. This thesis may seem to resemble the myth of rights that has long been undermined by North American law and society research and the critique of law. When the context for research and analysis shifts, however, the angle of vision and understanding of the meaning of rights may shift dramatically as well. Activism under such circumstances may have a somewhat different relationship to law.

Upendra Baxi, like Neelan Tiruchelvam, is a law and society scholar deeply committed to the cause of human rights in his native India and in global society. Like Neelan's vision of human rights, Upendra's interpretation of the human rights potential of 
law is grounded in an experience that is very different from that of the economically powerful and gilded societies of the world.

$\mathrm{He}$ is, in his own words, "a social activist who believes that human rights have a future only when human suffering is taken seriously" (Baxi 2000:1184). Human rights arise from the moral claims of those who suffer. His vision grows in part from his extensive research and reflection on the conditions of oppression in India and activism for social change. He has studied, for example, the success of constitutional social action litigation in India in asserting moral claims on behalf of the oppressed (1987). Social action litigation-unlike public interest litigation, familiar in the United States-includes many attributes of a social movement, such as mobilizing community activists and the press as well as courts. The oppressed in India include women in protective custody, bonded laborers, untouchables and scheduled tribes, slum dwellers and pavement dwellers, and many others. Initially, their claims had no explicit foundation in the language of India's Constitution. Social action litigation not only validated many of their moral claims, but it also had the surprising consequence of increasing the legitimacy of the court and the Constitution itself. Social action litigation in India expressed a powerful moral sentiment, incorporating many of the features of a social movement. Ultimately, it created a new charter between the people and the government.

Upendra's activism and research have been mutually reinforcing. As a scholar he rejects postmodern theory of the fractured and decentered subject because the experience of oppression that he has observed creates concrete identities; as an activist he rejects technocratic and statist human rights that ignore the claims of the oppressed based on their suffering. He embraces instead a reconstruction of human rights grounded in the experience of suffering.

We would do well not to underestimate the power of Baxi's insights. In countries with less institutional or economic stability, activists may look to law in ways that have been forgotten in more stable democracies. Nevertheless, Upendra's description of the moral power of legal claims by the oppressed in India may speak more directly to the American experience. Many decades of successful civil rights litigation in the United States greatly increased the moral power of the law and the Constitution. Perhaps for this reason, Baxi's research resonates with critical race theory in North America. Like Baxi, minority scholars in the United States brought a different angle of vision, and a different sense of the stakes, to the critique of rights.

Upendra's work reminds us that, under the right conditions, the law has power to invite and to give effect to new visions of society. 
Setsuo Miyazawa, like Upendra Baxi, is a scholar whose activism has been shaped by the context of his own society and his research. Law is a focal point of progressive change and activism in the political evolution of Japan, one of the world's most economically developed societies. The contemporary Japanese judicial system dates from the late 19th century, and it was never intended to provide access to courts or democratic accountability for ordinary people. As an activist, Setsuo Miyazawa advocates liberalization of the requirements for entry into the legal profession and liberal reform of the courts to make them more accessible to ordinary citizens. Expectations by modern-day activists, like Setsuo, that liberal legal reform might be a vehicle for greater accountability and more effective enforcement of rights may seem doomed to Americans familiar with the law and society research on the failures of liberal legalism, but such a response fails to account for the cultural context of his activism.

Setsuo's (Miyazawa 1998; Kidder and Miyazawa 1993) research on class litigation to remedy the effects of environmental disasters, as well as litigation for remedies for unjust government practices, suggests that liberal reforms may increase government accountability. In Japan, according to Setsuo and other law and society scholars, the barriers to accountability through litigation lie in the judicial system itself and in the lack of lawyers to bring cases, not in an absence of plaintiffs who might bring such litigation. There is a long tradition of public interest litigation in Japan that demonstrates that large numbers of Japanese citizens desire greater accountability from government officials. Like the social action litigation described by Upendra Baxi, one of the principal goals of public interest litigation (in Japan) has been to mobilize public support for accountability. Unlike social action litigation in India, however, the Japanese courts have seldom responded favorably. Nevertheless, Setsuo concludes that public interest litigation in Japan expresses, in his words, "a diffuse sense of injustice and attempts to use the law to correct [the denial of rights]." "In that sense," he says, "the overall context of cause lawyering in Japan appears to be very similar to . . Third World countries ... Where the rule of law is not firmly established, liberal legalism can be the cutting edge of cause lawyering. In spite of its tremendous economic development, Japan is such a country politically" (Miyazawa 1999:14).

As Setsuo observes, the cultural context of his outspoken activism is significant. Few Japanese scholars speak for progressive judicial reform. He is the only scholar in that country ever to have opposed the appointment of a Supreme Court Justice. Setsuo's political opponents have criticized his proposals for reform because, they argue, such proposals are inconsistent with Japan's distinctive judicial system and legal culture. Setsuo contends that such arguments deploy Japan's unique culture to defend the sta- 
tus quo. He writes, " $[\mathrm{M}]$ any intellectuals now understand that culture itself has been a political creation" (Miyazawa 1999). However, few have chosen to follow his strong lead toward progressive reform. Because he is a progressive reformer and because he is identified with an international field of scholarship, Setsuo must carefully negotiate his identity in order to maintain legitimacy as an activist.

My last example brings social inquiry still closer to political action. Through outreach by the Program Committee, some of our colleagues have been able to attend this meeting, though neither their home institutions nor the nature of their human rights work ordinarily enable them to attend meetings like this one. Through NGOs and community-based organizations, they are engaged in a form of democratic political praxis that involves them simultaneously in research, popular education-and action. One such colleague with us today is human rights activist and scholar Alda Facio from Costa Rica. I will talk about her work and its connections to participatory research momentarily.

Participatory research emerged from popular movements for liberation in Asia, Africa, and Latin America in the 1970s; and hundreds of projects exist today throughout these regions, as well as in North America and Europe. Its ideology found expression, in part, in Freire's (1970) Pedagogy of the Oppressed, and, through reconstruction and articulation by Freire and other scholars, it has greatly influenced academics and activists in the North. Participatory research, observes Colombian scholar and activist Orlando Fals-Borda, is "not exclusively research oriented," nor is it only adult education, nor only sociopolitical action-it "encompasses all these aspects together" (1991:3).

Participatory research is emancipatory and pragmatic. For example, Fernando Rojas, former director of Instituto Latinoamericano de Servicios Legales Alternativos (ILSA), describes participatory research as an important element of struggles for fundamental social change in Latin America and elsewhere. The unreliability of a rights-only approach in the third world leads progressive lawyers to pursue popular education, local networking, organization building, and encouragement of an "ongoing process of action, reflection, and action" (Ardila and Clark 1992:112) by client communities, which is the essence of participatory research. In all of its forms, participatory research helps participants discover and understand the limits of existing political and legal institutions and helps them think of themselves as agents of change.

Participatory research has much in common with feminist methodology, which denies the academic researcher exclusive interpretive authority (Harding 1986). Like alternative lawyering, participatory research instantiates the activism in critical race and critical feminist scholarship, which "speaks in the voice of 
the other" (see White 1990). Strong bonds now exist between law and society activists in the South and in the North who incorporate participatory practices into their research.

Alda Facio is an internationally recognized expert on women and the law and is a director of several United Nations programs. As a prominent scholar, she represents the Costa Rican government in many international organizations and conferences. At the same time, she is an outspoken feminist and lesbian, deeply committed to transforming conditions in her own society. For example, she has not shied from confrontation with Costa Rica's archbishop, who, as you might suspect, is not one of her strongest supporters.

Among the most compelling themes of Alda's writing as a scholar and a human rights activist is the importance of achieving a new consciousness of gender (Facio 1998, 1999). She is aware that a new consciousness requires not only public education about the problems of exclusion, discrimination, and violence linked to gender but a new way of thinking. Change will come about only by gathering information from one's own experiences and processing it in a new way-the very core of participatory research.

Her scholarship and her activism have focused on the need for a practice of consciousness raising. Like Upendra Baxi, she argues that human rights must be perceived through a new lens; namely, gender. Gender is a lens through which every human being views the world. Current concepts of human rights lack gender consciousness. Thus, Alda Facio (1998) argues that current human rights concepts fail not because they do not include special protections for women, but because they do not incorporate a consciousness of the full range of gender experiences and gender oppression into the fundamental terms in which all human rights are expressed.

Alda Facio confronts human rights language that unconsciously incorporates only male awareness of the world with the consciousness-discovering and consciousness-raising techniques of participatory research. Latin American feminists have extensive experience with popular education that incorporates sharing and processing experience. Countering abstract rights talk with concrete experiences invites greater self-awareness rather than polarization and confrontation. Participatory research has provided a powerful methodology, one of many applied by Alda, to carry her human rights struggle from the villages of Latin America to the classrooms of law schools, and even to the forums of the United Nations.

$$
* * *
$$

The work of Tiruchelvam, Baxi, Miyazawa, and Facio reflects a broader global concern with governance. For many unstable or 
rapidly changing societies in the post-cold war world, the emerging central issue is governance.

Governance is hotly contested terrain. Powerful international institutions supporting free trade pressure third world countries to adopt reforms associated with the first world's ethnocentric and free market dominated vision of "good governance." Amartya Sen (1999) agrees that governance is important, but only when it puts democracy, education, and health care ahead of the accumulation of wealth. Sen notes that no truly democratic society has ever had a famine. Further, his research shows that Asian societies laid a foundation for economic growth by building a broad base for social welfare, education, and food production, unlike high GNP societies in Latin America, where the quality of life is still extremely low for a large portion of the population. He concludes that the market can be an important, but clearly subordinate, tool for achieving economic development and quality of life.

For Sen, but also for law and society scholars, governance is a central human rights issue.

Law and society's distinctive role may be the study of social governance in all of its forms. The law and society field examines the cultural and institutional mediums of power and legitimacy. Our research is increasingly about individuals situated in familiar forms of social life-organizations, families, neighborhoods, and communities. From the perspectives of many disciplines in many societies we study the ways that mediums of power and legitimacy are related to the way we speak, act, and think in our relationships with one another. Most importantly, law and society scholars are in a position to consider what that means for a community's or a society's efforts to achieve a greater quality of life through governance in all its public and private forms.

As our field's knowledge has expanded so have its humanitarian concerns. In the spirit of Lawrence Friedman's remark, governance is too important to leave to the bankers, regulators, investors, international lawyers, and political leaders of the world. They should not be allowed to define governance or deploy it at will as a symbol for their own purposes. So, here is an activist project of the greatest importance that we have discovered through our research and that has already been embraced by many in the law and society field.

\section{Activism as Taking Responsibility for Consequences}

Activism emerges in a different way in each of my illustrations. In conclusion, I want to consider what we might learn from these examples of law and society scholarship that is intellectually profound yet is engaged with humanitarian social change. 
Neelan Tiruchelvam was an eloquent world human rights leader. But world leadership is not required for activism; nor is radical political action. Nor should our research be turned to the narrow instrumental concerns of a politics of the moment.

Nevertheless, leadership of another kind might enhance activism. The Law and Society Association (LSA) and its counterparts in other countries could take steps to make issues of justice and equality, on which our research bears, the focus of discussion and action. The Law and Society Association could create a forum for discussion of research on law and the possibilities for social change serving humanitarian values and the achievement of greater well-being through transformation of governance. That forum would include both law and society scholars and others.

The Quakers, longtime models for international humanitarian activism, might suggest that we make this the work of a Peace and Action Committee. Quaker activism has two components-forthrightness and tenderness. Forthrightness requires expressing beliefs about rightness rooted in the Quakers' humanitarian values. Tenderness expresses a regard for the values and participation of others. In the law and society field, the principle of forthrightness might suggest that we have a responsibility to make the implications of our research clear to others. The principle of tenderness implies a willingness to be open minded about the relevance of our research and about the interpretation of our observations.

Law and society activism requires neither our presence on the barricades nor that we authorize the Law and Society Association to speak for us on policy and politics. The scholarship of Upendra Baxi, Setsuo Miyazawa, and Alda Facio suggests a part for each of us who feels the pull of activism. I contend that activist scholars are and should be concerned about the implications of their research for the achievement of a better society.

I recently participated in a conference on the future of the Americans with Disabilities Act (ADA), at which David Engel and I presented some of our life-story research exploring the role of rights in the actual experiences of intended rights holders (Engel and Munger 2001). Many of the conference participants were litigators and legislative lawyers seeking to make the promises of the ADA come to fruition. They wanted to hear about our research because it bears on the value of their work. At the same time, they were frustrated by our message that the effects of civil rights for our interviewees were at best contingent and indirect. As David pointed out after the conference, the litigator activists had no way to incorporate what we said into their appellate litigation; and in the end our participation seemed quite marginal to the principal discourses of the conference. And we did not help them bridge that gap. 
Similar stories arise in many areas of our field's experience. Critique intrigues but is not readily assimilated by activist lawyers. Cultural complexities interest but also sometimes anger human rights advocates, who say the stakes require action. Empirical complexity with little apparent pragmatic significance, they say, is a prescription for paralysis.

The research and practice of an emerging group of activist scholars in the law and society field establishes a different pattern by our examining the conditions and circumstances of an effective politics of rights. I contend that activism has a legitimate place among the norms of inquiry. Our research, whether about everyday life or about formal institutions, whether reflexive and hermeneutic in inspiration or positivist and quasi-experimental in method, has increasingly emphasized the constitutive elements of law and legal process. We might describe the activism in our research as a commitment to "completing the constitutive loop," borrowing a wonderfully suggestive phrase used by Sara Cobb during discussion at a recent conference on the subject "What Do Rights Do?" The call of activism to "complete the constitutive loop" urges our examination of the connection between our research and change. An investigator sensitive to the importance of the constitutive loop will think carefully about the processes that currently mediate change and those that might mediate change in the future.

For the activist, the most satisfying research reshapes understanding in ways that open new paths for activism. On one hand, research speaks directly to activism when it is critical and reconstructive. On the other hand, research always presents a contingent vision of reconstruction. Thus, social inquiry makes activism more effective but makes the direction and strategy of activism contingent upon the scholars' unanticipated findings.

In turn, activism makes inquiry contingent. Activism motivates by making research particularly exciting when it enables change. However, if we take our activism seriously, we ought to make conditions and strategies for change part of our research agenda. Thus the commitment to activism may render our research agenda contingent upon an evolving model of historical relevance.

Even if we redirect our energy to understanding the possibilities for achieving the goals our research serves in the real world, our role as activists is not quite complete. Tiruchelvam, Baxi, Miyazawa, Facio-and Bette Sikes-remind us of the importance of completing the constitutive loop through public educationspeaking so that we are heard. Upendra Baxi writes,

I also believe that clarity of conviction and communication is a crucial resource for promoting and protecting human rights.

Success in this performance is never assured, but the struggle to attain it is by itself a human rights task. (1998:128) 
The strength of the law and society movement in social inquiry, and the source of its activism, is its moral vision. Cornell West observed that

one of the reasons the civil rights movement by Martin Luther King, Jr., is remembered more than, say[,] other equally worthy ones such as the CIO-led unionization movement or the feminist movement is that its moral vision was central to its identity and accented by its major spokesperson. (1998:717)

Early in her career, Joyce Ladner concluded that her research, in the end, was about "winning this revolution in women's rights" (1971:xv). She wrote,

Where do we go from here? How do we find common ground for cooperation? How do we cross barriers of race and class? First, we must cross them because it is the right thing to do ... it is the moral thing to do. We should not cooperate with a society that practices discrimination. We should work to break down the barriers that impede women's progress because we want to ensure that everyone has the opportunity to reach her full potential whether she is a poor welfare mother or a college professor. (ibid)

The humanitarian values that inspired a civil rights movement, as well as movements for equality, freedom, and greater quality of life in other parts of the world, also inspire the law and society movement. As West and Ladner tell us, this is a considerable strength and well worth the commitment of law and society scholars.

\section{References}

Ardila, Edgar and Jeff Clark (1992) "Notes on Alternative Legal Practice in Latin America," Beyond Law March: 107-13.

Baxi, Upendra (1987) "Taking Suffering Seriously: Social Action Litigation in the Supreme Court of India," in Tiruchelvam and Coomaraswamy (eds) The Role of the Judiciary in Plural Societies. New York: St. Martin's Press: 3-60. - (1998) "Voices of Suffering and the Future of Human Rights," 8 Transnational Law and Contemporary Problems 125-69.

- (2000) "Constitutionalism As a Site of State Formative Practices," 21 Cardozo Law Review 1183-1210.

Engel, David and Frank Munger (2001) "Reinterpreting the Effect of Rights: Career Narratives and the ADA," 62 Ohio State Law Joumal 285-334.

Facio, Alda "A Word (or Two) about Gender and the Creation of an International Criminal Court," downloaded from www.cwgi.rutgers.edu/ gcnews $98 /$ n113.

(1999) "The Law: An Art or a Science?" 7 American University Journal of Gender, Social Policy and the Law 355-72.

Fals-Borda, Orlando (1991) "Some Basic Ingredients," in Fals-Borda and Rahman (eds) Action and Knowledge: Breaking the Monopoly with Participatory Action-Research. New York: Apex Press.

Freire, Paulo (1970) Pedagogy of the Oppressed. New York: Herder and Herder.

Harding, Sandra (1986) The Science Question in Feminism. Ithaca, NY: Cornell University Press. 
Kidder, Robert and Setsuo Miyazawa (1993) "Long-term Strategies in Japanese Environmental Litigation," 18 Law $\mathcal{E} 0$ Social Inquiry 605-27.

Ladner, Joyce (1971) Tomorrow's Tomorrow: The Black Woman. Lincoln, Nebraska: University of Nebraska Press.

Mills, C. Wright (1959) The Sociological Imagination. New York: Oxford University Press.

Miyazawa, Setsuo (1998) "Lawyering for the Underrepresented in the Context of Legal, Social, and National Institutions: The Case of Japan." Paper presented at the Conference on Providing Legal Services for Underrepresented Groups in East and Southeast Asia: Creating a Forum for Dialogue, Bangkok, Thailand, July, 1998.

(1999) "Lawyering for the Underrepresented and the Changing Political Environment of the Bar in Japan." Revised version of a paper presented at the Conference on the Legal Profession in East Asia, Cambridge, MA, December, 1998.

Rojas, Fernando (1988) "A Comparison of Change-Oriented Legal Service in Latin America with Legal Services in North America and Europe," 16 International Journal of the Sociology of Law 203-56.

Santos, Boaventura de Sousa (1998) "Oppositional Postmodernism and Globalizations," 23 Law E' Social Inquiry 121-39.

Sen, Amartya (1999) Development As Freedom. New York: Knopf.

Tiruchelvam, Neelan (1987) "Introduction," in Tiruchelvam and Coomaraswamy (eds) The Role of the Judiciary in Plural Societies. New York: St. Martin's Press: vii-xxi.

West, Cornell (1998) "The Role of Law in Progressive Politics," in Kairys (ed) The Politics of Law. 3d ed. New York: Basic Books.

White, Lucie (1990) "Goldberg $v$. Kelly: On the Paradox of Lawyering for the Poor,” 56 Brooklyn Law Review 861-87.

\section{Statutes Cited}

Americans with Disabilities Act, 42 U.S.C. sec. 12101 (a)(1) (1994) 